\title{
Ortaöğretim Öğrencilerinde Fen Öğrenmeye Yönelik Kaygı ve Motivasyon İlişkisi
}

\author{
Ece E. MÜEZZİN ${ }^{1}$, Beste Ç. ÖZATA ${ }^{2}$
}

\begin{abstract}
Özet: Fen ve Teknoloji derslerinin önemini dikkate aldığımızda öğrencilerin motivasyonları ve kaygı düzeylerinin araştırılması gerekliliği ortaya çıkmaktadır. Bu araştırmanın Fen ve Teknoloji dersine ilişkin motivasyon ve kaygı arasındaki ilişkiyi belirlemede alınyazına katkı sağlaması bakımından önemlidir. Bu araştırmada ortaöğretim öğrencilerinin fen bilimlerini öğrenmeye yönelik kaygıları ve fen eğitimine yönelik motivasyon düzeylerinin incelemesi amaçlanmıştır. Araştırmada öğrencilerin fen derslerinin yoğun olarak görüldüğü kolejlerde öğrenci olmak ölçüt olarak alınmıştır. \%42,2 (n=231) erkek ve \%55,8 (n=292) kadın olmak üzere toplam 523 kolej öğrencisi çalışmaya katılmıştır. Veri toplama aracı olarak Yıldırım (2015) tarafından geliştirilen Fen Bilimleri Öğrenme Kaygı Ölçeği (FBÖKÖ), Dede ve Yaman (2008) tarafından geliştirilen Fen Öğrenmeye Yönelik Motivasyon Ölçeği (FÖYMÖ) ve kişisel bilgi formu uygulanmıştır. Sonuç olarak fen bilimini öğrenme kaygısı ile fen öğrenimine yönelik motivasyon arasında orta ve düşük düzeyde negatif yönde ilişki bulunmuştur. Buna göre fen bilimine yönelik kaygı yükseldikçe fen öğrenimine yönelik motivasyonun düştüğünü, kaygı düştükçe de motivasyonun yükseldiği ortaya konmuştur. Araştırma sonuçlarına göre önerilerde bulunulmuştur.
\end{abstract}

Anahtar kelimeler: Fen eğitimi, kaygı, motivasyon.

The Relation between Anxiety and Motivation for Learning Science in Secondary School Students

\begin{abstract}
Considering the importance of science and technology classes, it becomes evident that the motivation and anxiety levels of students have to be examined. This study is important in that it will make contribution to the literature in determining the relation between motivation and anxiety as regards science and technology classes. The objective of this study is to examine the anxiety among secondary school students for learning science and their level of motivation for science education. The research used the criterion of being a student at a college where science classes are more intense. A total of 523 college students, $42.2 \%(\mathrm{n}=231)$ are male and $55.8 \%(n=292)$ are female contributed to the study. Science Learning Anxiety Scale (FBÖKÖ) developed by Yıldırım (2015) and Motivation Scale for Learning Science (FÖMYÖ) developed by Dede and Yaman (2008) as well as a personal information form was used as data collection tools. In conclusion, medium and low-level negative correlation was identified between anxiety for learning sciences and motivation for science learning. Accordingly, it has been displayed that as anxiety for science learning increases, motivation for science learning decreases whereas as anxiety decreases, motivation increases. Recommendations are provided based on the findings of the study.
\end{abstract}

Keywords: Science education, anxiety, motivation.

${ }^{1}$ Yrd. Doç. Dr. Ece E. Müezzin, Kıbrıs Sosyal Bilimler Üniversitesi, Fen-Edebiyat Fakültesi, Psikoloji Bölümü, LefkoşaKibris

${ }^{2}$ Öğr. Gör. Beste Ç.Özata, Kıbrıs Sosyal Bilimler Üniversitesi, Fen-Edebiyat Fakültesi, Psikoloji Bölümü, Lefkoşa-Kıbrıs

Address of correspondence/ Yazışma adresi: Yrd. Doç. Dr. Ece E. Müezzin, Kıbrıs Sosyal Bilimler Üniversitesi, FenEdebiyat Fakültesi, Psikoloji Bölümü, Lefkoşa-Kıbrıs. Email:ece.muezzin@kisbu.edu.tr

Date of Received/ Geliş Tarihi: 18.04.2019, Date of Acceptance/ Kabul Tarihi: 30.04.2019

Citing/Referans Gösterimi: Müezzin, E., Özata, B. (2019). Ortaöğretim Öğrencilerinde Fen Öğrenmeye Yönelik Kayg1 ve Motivasyon İlişkisi. Kıbrı Türk Psikiyatri ve Psikoloji Dergisi, 1 (1): 14-21 doi:10.35365/ctjpp.19.1.02 


\section{Giriş}

Fen bilimleri dersi gözlemlenen doğa ve doğa olaylarını inceleyen, tanımlayan, kontrol etmeye ve önceden tahmin etmeyi öğretmeyi amaçlamaktadır (Akça, 2007). Teknoloji ise öğrencilere bilgiye anında ulaşma, değiştirme ve dönüt alma imkânı sağlamaktadır (Loveless, 2000). 2017 yılında Fen ve Teknoloji dersinin genel amaçları incelenmiş, yaşam boyu öğrenmeye açık bireyler yetiştirilmesi için güncellenmiştir (MEB, 2017). Gelişen ve değişen dünyada ihtiyaç duyulan öğrenci profili araştırmaya ve öğrenmeye istekli, sorgulayan, mantıksal bağ kurmaya çalışan, neden- sonuç ilişkisi kurabilen bireylerdir. Fen ve Teknoloji dersi bu becerileri kazandırıldığı derslerin başında gelmektedir (Atay, 2014). Fen eğitiminden sağlanan başarıda öğrencilerin eleştirel ve bilimsel düşünme kapasitelerinin gelişiminde oldukça önemli bir yeri vardır (Özkan, 2003; Wolters ve Rosenthal, 2000). Toplumun değişimine ve gelişimine ayak uydurabilen ve güçlü bir nesil yetiştirmek için Fen ve Teknoloji eğitimi önemli rol oynadığ1 gözlemlenmektedir (Çavuş ve Özden, 2012). Gelişmekte olan ve gelişmiş ülkelerin en fazla önem verdiği derslerin başında geldiği düşünülmektedir.

Fen ve Teknoloji dersinin öğrenilebilmesi için derste aktif bir şekilde yer alınması gerekmektedir. Etkili ders öğretimi, öğrencileri yaparak yaşayarak öğrenme olanağı sağlanmalı ve normal hayatlarında nasıl kullanabilecekleri öğrencilere aktarılması gerekmektedir (Gürbüz ve Coştu, 2004). Fen dersini öğretmenden bilgi aktarımı şeklinde öğrenip konuları ezberlemeye çalışan ve başarısızlığ deneyimleyen öğrenciler fen derslerinden hoşlanmamaya ve kaçınmaya başlarlar. Araştırmacılar, öğrencilerin çoğunun fen derslerinin zor olduğuna inandıklarını ve fen alanındaki başarılarının da düşük olduğunu belirtirler (Chen vd., 2012; Eroğlu ve Bektaş, 2016 ). Fen dersleri uygulamaya değil ezbere yönelik bilgiler halinde verildiği ve öğrencilere anlamlı gelmediği için çoğunluğu başarısız olan öğrenciler Fen derslerinden korkmakta ve sosyal bilimlere yönelmektedirler (Çoban ve Ergin, 2008). Fen dersine ilişkin yaşanan bu durum kaygı ortaya çıkarmıştır. Kaygı genel anlamda organizmanın bir uyarıcı ile karşılaştığında bedensel, duygusal ve zihinsel değişimlerle ortaya çıkan genel uyarılmışlık halidir (Cüceloğlu, 2016). Kaygıyla ilgili literatürde birçok farklı tanımda bulunmaktadır (Aral ve Başar, 1998; Burkovik, 2010; Morgan, 2000). Kayg1 kendi içinde ikiye ayrılmaktadır. Olumlu kaygı, öğrenciyi davranışı yapmaya teşvik etmekte ve başarıyı elde etmede motive edici özelliğe sahiptir fakat olumsuz kayg1 ise öğrencinin başarısını düşürmekte ve öğrenmeyi zorlaştırmaktadır (Akgün, Gönen ve Aydın, 2007;
Baltaş ve Baltaş 2008; Cüceloğlu 2016; Shovel, 1978). Fen kayg1s1 ise, dersi öğrenmeye ve hoşlanmaya ilişkin yaşadığı davranışsal, duyuşsal ve davranışsal öğelerden oluşan duygu durumudur. Buna ek olarak sadece öğrenmeyle ilgili değil kendi kendine verdiği mesajlarla da alakalıdır (Mallow ve Greenburg, 1982; Wynstra ve Cumming, 1990). Öğrencilerin fen ve teknoloji dersine yönelik kötü tecrübeleri, dersin öğretmenleriyle yaşadıkları, derse ilişkin olumsuz ve hatalı düşünce yapıları kaygılarının temelini oluşturmaktadır (Erökten, 2010). Öğretmenlerin Fen, Matematik ve Yabanc1 Dil öğrenme süreçlerinde öğrencileri olumsuz etkileyen kaygı duygusunu olumluya dönüştürebilmeleri öğrenme yaşantılarını düzenlemeleri ile mümkün olabilecektir (İlhan ve Öner-Sünkür, 2012; Yenice, Saydam ve Telli, 2012).

Fen derslerinin genel amaçları arasında; öğrencilerin temel Fen kavramlarını öğrenmeleri, bunları günlük yaşamlarına aktarabilmeleri, ayrıca derste ve ev ödevlerinde motive olmuş bir şekilde çalışmaları bulunmaktadır (Çeliker, Tokcan ve Korkubilmez, 2015). Hangi seviyede olursa olsun öğrencilerin öğrenmeleri için motivasyona ihtiyaç duymaktadır (Karakaya, Yılmaz ve Avgın, 2018). Motivasyon, bireyin bir amaç doğrultusunda harekete geçmesini, yürütebilmesini ve ayni zamanda sonlandırabilmesini sağlayan en önemli etmendir (Glynn, Taasoobshirazi ve Brickman, 2009; Watters ve Ginns, 2000). Motivasyon öğrenmeyi etkileyen en önemli unsurlarından biridir ve ayni zamanda gözden kaçırılmaması gereken etmenlerin başında gelmektedir. Motivasyon içsel ve dışsal etmenleri de içeren bir yapıya sahiptir (Dede ve Yaman, 2008). Fen ve Teknoloji eğitimine dişsal motivasyon ilişkin, öğretim programı, yöntemi, tekniği, öğrenme ortamı ve öğretecek kişi ve içsel motivasyon ise öğrenim görecek olan öğrencilerinin bireysel özellikleri, merak duyguları, keşfetme isteklerini de kapsayan geniş bir yelpazedir (Belo vd., 2010; Yenice, Saydam ve Telli, 2012; Yılmaz ve Çavaş, 2007). Öğrenmenin tanımını yaparken davranış değişikliğinden söz edilir bu değişiklik içinde motivasyona ihtiyaç duyulmaktadır (Sevinç vd., 2011). Motivasyonu düşük olan öğrencilerin başarı düzeylerinde de düşüş olduğu tespit edilmiştir (Engin, 2009). Öğrencilerin fen dersi ile ilgili olarak kavramları daha iyi öğrenebilmek ve dersteki başarılarının artması için motive olmaları gerekmektedir (Uzun ve Keleş, 2010). Yüksek motivasyonlu öğrenciler daha azimli, heyecanlı, meraklı öğrenmeye 1srarlı oldukları tespit edilmiştir (Wolters ve Rosenthal 2000). Yapılan araştırmalara bakıldığında akademik başarı üzerinde olumlu etkileri olduğu bulunmuştur (Alkan ve Bahri, 2017; Demir vd., 2012; Kuyper, Van der Werf ve Lubbers, 2000). 
Fen ve Teknoloji derslerinin önemini dikkate aldığımızda öğrencilerin motivasyonları ve kaygı düzeylerinin araştırılması gerekliliği ortaya çıkmaktadır. $\mathrm{Bu}$ araştırmanın Fen ve Teknoloji dersine ilişkin motivasyon ve kaygı arasındaki ilişkiyi belirlemede alınyazına önemli katkı sağlayacağı düşünülmektedir.

$\mathrm{Bu}$ araştırmada ortaöğretim öğrencilerinin fen bilimlerini öğrenmeye yönelik kaygıları ve fen eğitimine yönelik motivasyon düzeylerinin incelemesi amaçlanmıştır. $\mathrm{Bu}$ amaç doğrultusunda “Ortaöğretim öğrencilerinde fen bilimleri öğrenme kaygıs1 ve fen öğrenmeye yönelik motivasyon arasında istatistiksel olarak anlamlı ilişki var mıdır ?" sorusuna ve bu probleme dayalı olarak aşağıdaki alt problemlere yanıt aranmıştır.

\section{Alt Problemler}

- Ortaöğretim öğrencilerinin fen bilimleri öğrenme kaygıları ne düzeydedir?

- Ortaöğretim öğrencilerinin fen öğrenmeye yönelik motivasyonları hangi düzeydedir?

- Ortaöğretim öğrencilerinde fen bilimleri öğrenme kaygısı ve fen öğrenmeye yönelik motivasyon alt boyutları arasında istatistiksel olarak anlamlı ilişki var mıdır? Varsa nelerdir?

\section{Yöntem ve Gereç}

\section{Araştırmanın Modeli:}

$\mathrm{Bu}$ araştırma yöntemsel olarak betimsel bir araştırmadır. Betimsel araştırma modelinde olay olduğu gibi araştırılmaktadır. Ele alınan olay, olgu ve durumlar ayrıntılı şekilde araştırılarak daha önceki durumlarla ve olaylarla ilişkisi incelenip bunların neler olduğu betimlenmeye çalışılmaktadır
(Karakaya, 2009). Bu araştırma modeline bağlı olarak nicel veriler toplanarak orta öğretim öğrencilerinin fen öğrenimine yönelik kaygı ve motivasyon düzeyleri incelenmiştir. Nicel araştırmalar sayısal verilerin toplandığı, analiz edilip yargıya varıldığı, deney, gözlem, belgeleme, araştırma-soruşturma ile yapılan bir araştırma tekniğidir (Sönmez ve Alacapınar, 2011).

\section{Evren ve Örneklem}

Araştırmanın evreni KKTC de bulunan tüm ortaöğretim kurumlarını kapsamaktadır. Araştırmanın örneklemi ölçüt örnekleme yöntemiyle belirlenmiş 523 kolej öğrencisinden oluşmaktadır. Ölçüt örneklem modeli, bir araştırmada gözlem birimleri belli niteliklere sahip kişiler, olaylar, nesneler ya da durumlardan oluşturulabilir. $\mathrm{Bu}$ durumda örneklem için belirlenen ölçütü karşılayan birimler (nesneler, olaylar vb.) çalışma grubuna alınırlar (Büyüköztürk vd., 2016). Lefkoşa, Girne ve Güzelyurt bölgelerinde yer alan kolejlerde eğitim gören öğrencilerden oluşan örneklem bireylerin ailelerine çalışma hakkında bilgilendirme yapılmış ve çocuğunun araştırmaya katılması için onam alınmıştır. Araştırmada öğrencilerin fen derslerinin yoğun olarak görüldüğü kolejlerden öğrenci olmak ölçüt olarak alınmıştır. \%42,2 (n=231) erkek ve \%55,8 (n=292) kadın olmak üzere toplam 523 kolej öğrencisi çalışmaya katılmıştır. Araştırmaya katılan öğrencilerin \%34,4'ü (n=180) Lefkoşa Türk Maarif Kolejinde, \%35,6's1 (n=186) Girne Türk Maarif Kolejinde ve \%30’u (n=157) Güzelyurt Türk Maarif Kolejinde eğitim görmektedirler. Öğrencilerin \%34'ü $(n=178)$ 6. sinıf, \%37,7'si $(n=197)$ 7. sinıf ve $\% 28,3^{\prime} \ddot{u} \quad(n=148) \quad 8$. sinıfa devam etmektedir. Örneklemin cinsiyet, okul ve sınıflara göre dağılımları Tablo 1'de, sunulmuştur.

Tablo 1. Örneklemin Cinsiyet, Okul ve Sınıf Dağılım Tablosu

\begin{tabular}{|c|c|c|c|}
\hline & & $\mathbf{n}$ & $\%$ \\
\hline \multirow{3}{*}{ Cinsiyet } & Kadın & 292 & 55,8 \\
\hline & Erkek & 231 & 44,2 \\
\hline & Toplam & 523 & 100 \\
\hline \multirow{4}{*}{ Okul } & Lefkoşa Türk Maarif Koleji & 180 & 34,4 \\
\hline & Girne Türk Maarif Koleji & 186 & 35,6 \\
\hline & Güzelyurt Türk Maarif Koleji & 157 & 30 \\
\hline & Toplam & 523 & 100 \\
\hline \multirow{4}{*}{ Sinif } & 6. $\sin 1 f$ & 178 & 34 \\
\hline & 7. $\sin 1 f$ & 197 & 37,7 \\
\hline & 8. sinif & 148 & 28,3 \\
\hline & Toplam & 523 & 100 \\
\hline
\end{tabular}




\section{Veri Toplama Araçları}

Araştırmada veri topla aracı olarak Fen Bilimleri Kaygı Ölçeği, Fen Öğrenmeye Yönelik Motivasyon Ölçeği ve Kişisel Bilgi Formu kullanılmıştır.

Fen Bilimleri Öğrenme Kaygı Ölçeği (FBÖKÖ), öğrencilerin fen bilimleri öğrenme kaygılarını ölçmek amacıyla Yıldırım (2015) tarafından geliştirilmiştir. 5' li Likert tipi olan bu ölçek (1: Kesinlikle Katılmiyorum, 2: Katılmıyorum, 3: Kararsızım, 4: Katıllyorum, 5: Kesinlikle Katılıyorum) 19 madden oluşmaktadır. Ölçeğin "Öğrenci, İçerik ve Öğretim", "Dersten Kaçınma" ve "Derse Yönelik Kaygı" olmak üzere 3 alt boyutu vardır. Ölçeğin Cronbach Alpha güvenirlik katsayısı, 85 olarak bulunurken; öğrenci, içerik ve öğretim boyut için ,88; kaçınma boyut için ,75 ve derse yönelik kaygı boyutu için ,63 olarak bulunmuştur. Ölçekten alınan yüksek puanlar fen bilimleri öğrenme kaygısının yüksek olduğunu ifade etmektedir.

Fen Öğrenmeye Yönelik Motivasyon Ölçeği (FÖYMÖ), Dede ve Yaman (2008) tarafindan geliştirilmiştir. 5' li Likert tipi olan bu ölçek tamamen katıliyorum (5), katılıyorum (4), kısmen katıliyorum (3), katılmiyorum (2), tamamen katılmiyorum (1) toplam 23 maddeden oluşmaktadır. Ölçek "Araştırma Yapmaya Yönelik Motivasyon", "Performansa Yönelik Motivasyon", "İletişime Yönelik Motivasyon", "İşbirlikli Çalışmaya Yönelik Motivasyon" ve "Katılıma Yönelik Motivasyon" 5 alt boyutu vardır. Ölçeğin Cronbach Alpha iç tutarlılık katsayısı, 80 olarak hesaplanmıştır. Çalışmanın kendisinde ölçme aracının her alt boyutu için iç tutarlılık katsayıları incelenmiş ve alt faktörlerin Cronbach Alpha güvenirlik katsayıları şöyledir; araştırma yapmaya yönelik motivasyon için, 75; performansa yönelik motivasyon için, 68 iletişime yönelik motivasyon için, 56, işbirlikli çalışmaya yönelik motivasyon için ,55 ve katılıma yönelik motivasyon için ,59 olarak bulunmuştur. Ölçeğin test-tekrar-test yöntemi Cronbach Alpha iç tutarlılık katsayısının, 82 olduğu ifade edilmiștir. Ölçekteki puanlar, 1 ile 5 arasında olduğundan, puanlar 5,'e yaklaştıkça öğrencilerin fen öğrenmeye yönelik motivasyon ve katılım düzeylerinin yüksek, 1'e yaklaştıkça ise düşük olduğu kabul edilmiştir.

Kişisel Bilgi Formu, örneklem hakkında araştırmanın amacına yönelik sosyo-demografik bilgi edinebilmek maksadıyla araştırmacılar tarafından hazırlanan 7 sorudan oluşan bir form uygulanmıştır.

\section{Veri Analizi}

Verilerin analizinde Sosyal Bilimler için İstatistik Programı (SPSS) kullanılmıştır. Verilerin analizinde araştırmanın amaçları doğrultusunda yüzdelik dökümleri, aritmetik ortalama, standart sapma ve Pearson Momentler Çarpımı Korelasyon katsayısı hesaplama yöntemleri kullanmıştır. $\mathrm{Bu}$ araştırmada istatistiksel olarak anlamlılık düzeyi ,05 olarak alınmıştır.

\section{Sonuçlar}

Yapılan bu çalışmada ortaöğretim öğrencilerinde fen bilimleri öğrenme kaygısı ve fen öğrenmeye yönelik motivasyon düzeyleri tespit edilmiştir. Ayrıca öğrencilerin fen bilimleri öğrenme kaygısı ve fen öğrenmeye yönelik motivasyonları arasındaki ilişki incelenmiştir.

Araştırmanın birinci alt problemi olan "Ortaöğretim öğrencilerinin fen bilimleri öğrenme kaygıları ne düzeydedir?" sorusuna her alt boyut için ortalama ve standart sapma hesaplamalarına göre elde edilen bulgular Tablo 2'de sunulmuştur.

Tablo 2. Fen Bilimleri Öğrenme Kaygı Ölçeği Puan Ortalama Tablosu

\begin{tabular}{lllll}
\hline Ölçek & Alt Boyutlar & N & $\bar{x}$ & ss \\
\hline \multirow{3}{*}{ Fen Bilimleri Öğrenme } & Öğrenci, İcerik ve Öğretim & 523 & 1,97 &, 76 \\
Kaygı Ölçeği (FBÖKÖ) & Dersten Kaçınma & 523 & 2,32 &, 90 \\
& Derse Yönelik Kayg1 & 523 & 2,42 &, 93 \\
& FBÖKÖ Toplam & 523 & 2,21 &, 78 \\
\hline
\end{tabular}

Fen Bilimleri Öğrenme Kaygı Ölçeği alt boyutlarına bakıldığında öğrencilerin derse yönelik kayg1 alt boyutu ortalamasının $(\overline{\mathrm{x}}=2,42 \pm, 93)$ diğer alt boyut ortalamalarına göre daha yüksek olduğu bulunmuştur. Sirasıyla diğer alt boyutlar değerlendirildiğinde desten kaçınma $(\overline{\mathrm{x}}=2,32 \pm, 90)$, FBÖKÖ toplam $(\overline{\mathrm{x}}=2,21 \pm, 78)$ ve öğrenci, içerik ve öğretim $(\bar{x}=1,97 \pm, 76)$ alt boyutlarının olduğu bulunmuştur.
Sonuç olarak öğrencilerin fen bilimleri öğrenme kayg1 ortalamalarının orta noktanın altında olduğundan öğrencilerin kaygı düzeylerinin yüksek olmadığını ortaya konmuştur.

Araştırmanın ikinci alt problemi olan “Ortaöğretim öğrencilerinin fen öğrenmeye yönelik motivasyonları hangi düzeydedir?" sorusuna her alt boyut için ortalama ve standart sapma hesaplamalarına göre elde edilen bulgular Tablo 3 'de sunulmuştur. 
Tablo 3. Fen Öğrenmeye Yönelik Motivasyon Ölçeği Puan Ortalama Tablosu

\begin{tabular}{|c|c|c|c|c|}
\hline Ölçek & Alt Boyutlar & $\mathrm{N}$ & $\overline{\mathrm{x}}$ & Ss \\
\hline \multirow{6}{*}{$\begin{array}{ll}\text { Fen } & \text { Öğrenmeye } \\
\text { Yönelik } & \text { Motivasyon } \\
\text { Ölçeği (FÖYMÖ) }\end{array}$} & Araștırma Yapmaya Yönelik Motivasyon & 523 & 3,57 & ,95 \\
\hline & Performansa Yönelik Motivasyon & 523 & 3,39 & ,88 \\
\hline & İletișime Yönelik Motivasyon & 523 & 3,59 & 89 \\
\hline & İşbirlikli Çalışmaya Yönelik Motivasyon & 523 & 3,13 & 67 \\
\hline & Katılıma Yönelik Motivasyon & 523 & 3,76 & 99 \\
\hline & FÖYMÖ Toplam & 523 & 3,48 & 65 \\
\hline
\end{tabular}

Tablo 3 incelendiğinde Fen Öğrenmeye Yönelik Motivasyon Ölçeği alt boyutlarına bakıldığında motivasyonun en düşük olduğu alt boyut işbirlikli çalışmaya yönelik motivasyon $(\bar{x}=3,13 \pm, 67)$ olduğu bulunmuştur. Sirasıyla diğer alt boyutlara bakıldığında performansa yönelik motivasyon $(\bar{x}=3,39 \pm, 88)$, FÖYMÖ Toplam $(\bar{x}=3,48 \pm, 65)$, araştırma yapmaya yönelik motivasyon $(\overline{\mathrm{x}}=3,57 \pm, 95)$, iletişime yönelik motivasyon $(\bar{x}=3,59 \pm, 89)$ ve katılıma yönelik motivasyon $(\bar{x}=3,59 \pm, 89)$ alt boyutlarının olduğu bulunmuştur.

Sonuç olarak fen öğrenmeye yönelik motivasyon alt boyut düzeylerinin ortalamanın üzerinde olduğu dolayısıyla öğrencilerin fen öğrenmeye yönelik motivasyonlarının orta düzeyin üzerinde olduğu ortaya konmuştur.

Araştırmanın üçüncü alt problemi olan Ortaöğretim öğrencilerinde fen bilimleri ögrenme kaygısı ve fen öğrenmeye yönelik motivasyon alt boyutları arasında istatistiksel olarak anlamlı ilişki var mıdır? Varsa nelerdir?" sorusuna Pearson Korelasyon Katsayısı hesaplaması yapılmış ve ölçeklerde yer alan alt ölçekler arasındaki korelasyon sonuçları Tablo 4'de sunulmuştur.

Tablo 4. FBÖKÖ ve FÖYMÖ Ölçek Puanları Korelasyon Tablosu

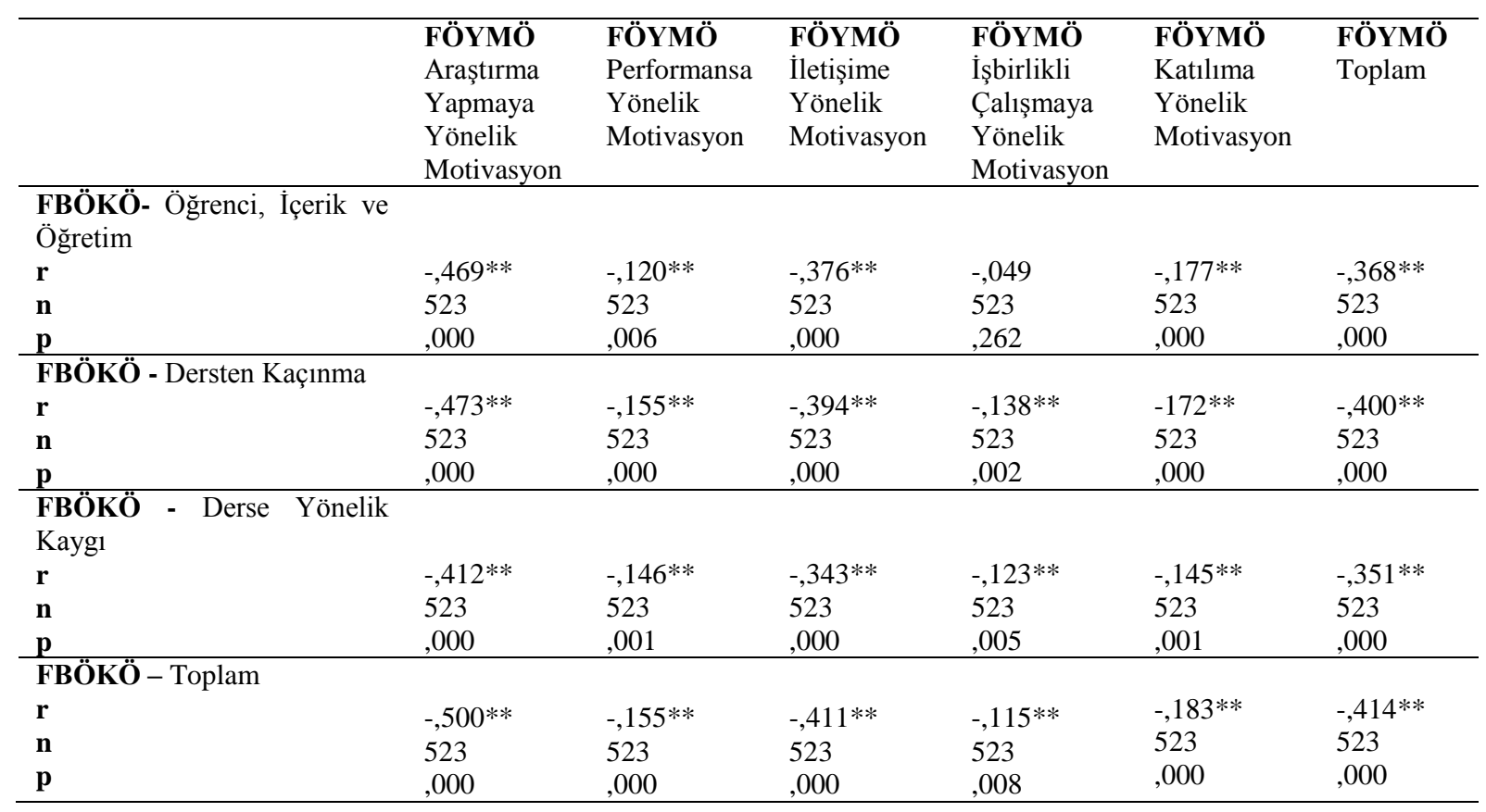

$* * \mathrm{p}<.05$ istatistiksel anlamlı ilişki

Korelasyon analizi sonucu; FBÖKÖ öğrenci, içerik ve öğretim alt ölçek puanı ile FÖYMÖ Araştırma Yapmaya Yönelik Motivasyon ( $\mathrm{r}=-.469, \mathrm{p}=.000)$, FÖYMÖ İletişime Yönelik Motivasyon ( $\mathrm{r}=-.376$, $\mathrm{p}=.000)$ ve FÖYMÖ toplam $(\mathrm{r}=-.368, \mathrm{p}=.000)$ arasında negatif yönde orta düzeyde istatistiksel anlamlı ilişki saptanmıştır. FBÖKÖ öğrenci, içerik ve öğretim alt ölçek puanı ile FÖYMÖ Performansa Yönelik Motivasyon ( $r=-.120, \mathrm{p}=.006)$ ve FÖYMÖ Katılıma Yönelik Motivasyon ( $r=-.177, p=.000$ ) arasında negatif yönde düşük düzeyde istatistiksel anlamlı ilişki saptanmıştır.

Müezzin, E. E., Özata, B. (2019).
FBÖKÖ dersten kaçınma alt ölçek puanı ile FÖYMÖ araştırma yapmaya yönelik motivasyon (r=-.473, p=.000), FÖYMÖ İletişime Yönelik Motivasyon ( $\mathrm{r}=-.394, \mathrm{p}=.000)$ ve FÖYMÖ toplam $(\mathrm{r}=-.400, \mathrm{p}=.000)$ arasında negatif yönde orta düzeyde istatistiksel anlamlı ilişki saptanmıştır. FBÖKÖ dersten kaçınma alt ölçek puanı ile FÖYMÖ Performansa Yönelik Motivasyon (r=$.155, \mathrm{p}=.000), \quad$ FÖYMÖ İşbirlikli Çalışmaya Yönelik Motivasyon ( $\mathrm{r}=-.138, \mathrm{p}=.002)$ ve FÖYMÖ Katılıma Yönelik Motivasyon ( $\mathrm{r}=-.172, \mathrm{p}=.000)$ 
arasında negatif yönde düşük düzeyde istatistiksel anlamlı ilişki saptanmıştır.

FBÖKÖ Derse Yönelik Kaygı alt ölçek puanı ile FÖYMÖ Araştırma Yapmaya Yönelik Motivasyon $(\mathrm{r}=-.412, \mathrm{p}=.000) \quad$ FÖYMÖ İletișime Yönelik Motivasyon ( $\mathrm{r}=-.343, \mathrm{p}=.000)$ ve FÖYMÖ Toplam $(\mathrm{r}=-.351, \mathrm{p}=.000)$ arasinda negatif yönde orta düzeyde istatistiksel anlamlı ilişki saptanmıştır. FBÖKÖ Derse Yönelik Kaygı alt ölçek puanı ile FÖYMÖ Performansa Yönelik Motivasyon ( $r=-$ .146, $\mathrm{p}=.001$ ) FÖYMÖ İşbirlikli Çalışmaya Yönelik Motivasyon ( $r=-.123, \mathrm{p}=.005)$ ve FÖYMÖ Katılıma Yönelik Motivasyon ( $\mathrm{r}=-.145, \mathrm{p}=.001)$ arasında negatif yönde düşük düzeyde istatistiksel anlamlı ilişki saptanmıştır.

FBÖKÖ toplam puanı ile FÖYMÖ Araştırma Yapmaya Yönelik Motivasyon ( $\mathrm{r}=-.500, \mathrm{p}=.000)$, FÖYMÖ İletişime Yönelik Motivasyon ( $\mathrm{r}=-.411$, $\mathrm{p}=.000)$ ve FÖYMÖ Toplam ( $\mathrm{r}=-.414, \mathrm{p}=.000)$ arasında negatif yönde orta düzeyde istatistiksel anlamlı ilişski saptanmıştır. FBÖKÖ toplam puanı ile FÖYMÖ Performansa Yönelik Motivasyon ( $\mathrm{r}=-$ $.155, \mathrm{p}=.000$ ) FÖYMÖ İşbirlikli Çalışmaya Yönelik Motivasyon ( $\mathrm{r}=-.115, \mathrm{p}=.008)$ FÖYMÖ Kat1lıma Yönelik Motivasyon ( $\mathrm{r}=-.183, \mathrm{p}=.008)$ arasinda negatif yönde düşük düzeyde istatistiksel anlamlı ilişsi saptanmıştır.

Sonuç olarak fen bilimini öğrenme kaygısı ile fen öğrenimine yönelik motivasyon arasında orta ve düşük düzeyde negatif yönde ilişki bulunmuştur. Buna göre fen bilimine yönelik kaygı yükseldikçe fen öğrenimine yönelik motivasyonun düştüğünü, kaygı düştükçe de motivasyonun yükseldiği sonucu ortaya konmuştur.

\section{Tartışma}

Yapılan bu araştırmada fen bilimini öğrenme kaygısı ile fen öğrenimine yönelik motivasyon arasındaki ilişki üzerine çalışılmıştır.

Demir, Öztürk ve Dökme (2012) tarafindan yapılan "İlköğretim 7. Sinıf Öğrencilerinin Fen ve Teknoloji Dersine Yönelik Motivasyonlarının Bazı Değişkenler Açısından İncelenmesi” konulu çalışma sonuçlarına bakıldığında araştırmaya katılan öğrencilerin fen öğrenmeye yönelik motivasyonlarının orta düzeyde olduğu tespit edilmiştir. Alkan ve Bayri (2017) yapılan "Fen Öğrenmeye Yönelik Motivasyon ile Fen Başarısı Arasındaki İlişki Üzerine Bir Meta Analiz Çalışmasıı" konulu çalışmada fene yönelik motivasyon ile fen başarısı arasında istatistiksel açıdan anlamlı ve pozitif bir ilişkinin olduğu görülmüştür.

Cavaş (2011) tarafindan yapılan "Factors affecting the motivation of Turkish primary students for science learning" konulu çalışma sonuçlarına bakıldığında ilköğretim öğrencilerinin fen motivasyonlarının cinsiyetlerine göre farklılık gösterdiğini ve öğrencilerin motivasyonu düzeylerinin fen tutumu ve fen başarısı üzerinde önemli bir etkiye sahip olduğu bulmuştur. Yapılan araştırmada da öğrencilerin fen öğrenmeye yönelik motivasyonlarının orta düzeyin üzerinde olduğu ortaya konmuştur. Belirtilen çalışmaların sonuçları yapılan çalışmanın sonuçlarını destekler niteliktedir.

Yolagiden ve Bektaş (2018) tarafindan yapılan "Sekizinci Sınıf Öğrencilerinin Fen Bilimleri Öğrenme Kaygıları ile Fen Bilimleri Öğrenme Yönelimleri Arasındaki İlişsinin İncelenmesi” konulu çalışma sonucunda öğrencilerin fen bilimleri öğrenme kaygıları ve fen öğrenimine yönelimleri arasındaki ilişkinin orta düzeyde, negatif yönde ve anlamlı olduğu tespit edilmiştir. Buna bağlı olarak öğrencilerin fen bilimleri öğrenme kaygıları arttıça fen öğrenimine yönelimleri azalmakta, fen bilimleri öğrenme kaygıları azaldıkça fen öğrenimine yönelimlerinin artmakta olduğu ortaya konmuştur. Durmaz ve Akkuş (2016) tarafindan yapılan "Mathematics Anxiety, Motivation and The Basic Psychological Needs from the Perspective of Self-Determination Theory" başlıklı çalışma sonuçlarına göre temel psikolojik ihtiyaçların matematik kaygısının etkisi önemli olduğu ortaya konmuştur. $\mathrm{Bu}$ sonuçlar göstermektedir ki öğrencilerin kendileri hakkında özerk kararlar vermeye teşvik etmek, matematiğe yönelik motivasyon ve matematiğe yönelik kaygı düzeyleri azaltmak gibi temel psikolojik ihtiyaçları sırayla desteklenmelidir sonucuna varılmıştır. $\mathrm{Bu}$ sonuçlar yapılan bu çalışmanın sonuçlarını destekler niteliktedir.

Sonuç olarak öğrencilerin fen bilimleri öğrenme kayg1 ortalamalarının orta noktanın altında olduğundan öğrencilerin kaygı düzeylerinin yüksek olmadığı, fen öğrenmeye yönelik motivasyonlarının orta düzeyin üzerinde olduğu ve fen bilimine yönelik kaygı yükseldikçe fen öğrenimine yönelik motivasyonun düştüğü, kayg1 düştükçe de motivasyonun yükseldiği sonucu bulunmuştur.

$\mathrm{Bu}$ çalışmaya koleje devam öğrenciler dâhil edilmiştir, kolej dışındaki ortaöğretim öğrencileriyle yapılması farklı sonuçlar ortaya koyabileceği düşünülmektedir. Bu çalışmada fen bilimi öğrenme kaygısı ile fen öğrenimine yönelik motivasyon arasındaki ilişkiye bakılmıştır. Araştırmacılara yönelik olarak yeni yapılacak olan çalışmalarda farklı değişkenlerin de fen bilimi öğrenme kaygısı ve fen öğrenimine yönelik motivasyon ile iliş̧kisine bakılması önerilmektedir. Betimsel türde olan çalışma, diğer çalışmalara 1 şık tutar nitelikte olup deneysel çalışmalarla da etkililiğinin araştırılması önerilmektedir. 


\section{Kaynaklar}

Akça, B. (2017). Ortaokul Öğrencilerinin Fene Yönelik Zihinsel Risk Alma Davranışları Ile Fen Kaygıları Arasındaki İlişkinin Belirlenmesi. Yayınlanmamış yüksek lisans tezi, Adnan Menderes Üniversitesi, Aydın.

Akgün, A., Gönen, S. ve Aydın, M. (2007). İlköğretim Fen ve Matematik Öğretmenliği Öğrencilerinin Kaygı Düzeylerinin Bazı Değişkenlere Göre İncelenmesi. Elektronik Sosyal Bilimler Dergisi, 6(20), 283-299.

Alkan, İ. ve Bahri, N. (2017). Fen Öğrenmeye Yönelik Motivasyon İle Fen Başarısı Arasındaki İliş̧i Üzerine Bir Meta Analiz Çalı̧̧ması. Dicle Üniversitesi Ziya Gökalp Eğitim Fakültesi Dergisi, 32, 865-874.

Aral, N. ve Başar, F. (1998). Çocukların Kaygı Düzeylerinin Yas, Cinsiyet, Sosyo-Ekonomi Düzey ve Ailenin Parçalanma Durumuna Göre İncelenmesi. Eğitim ve Bilim, 22 (110), 7-11.

Atay, A. D. (2014). Ortaokul Ögrrencilerinin Fen Öğrenmeye Yönelik Motivasyon Düzeylerinin ve Üstbilişsel Farkindaliklarının İncelenmesi. Yayınlanmamı̧ yüksek lisans tezi, Adnan Menderes Üniversitesi, Aydın.

Baltaş, Z. ve Baltaş, A. (2008). Stres ve Başa Çıkma Yolları. İstanbul: Remzi Kitabevi.

Belo, N. A. H., Driel, J. H. ve Verloop, N. (2010). Teachers' Beliefs About Making Physics Angaging and Comprehensible For Secondary Students in the Netherlands. M.F. Taşar \& G. Çakmakcı (Editör), Contemporary Science Education Research: Teaching. Ankara: Pegem Akademi.

Burkovik, Y. (2010). Kaygllanacak Ne Var! İstanbul: Timaș Yayınlar1

Büyüköztürk, Ş., Çakmak, E. K., Akgün, Ö. E., Karadeniz, Ş. ve Demirel, F. (2009). Bilimsel Araştırma Yöntemleri. Ankara,: Pegem Akademi.

Cavas, P. (2011). Factors Affecting The Motivation Of Turkish Primary Students For Science Learning. Science Education International, 22(1), 31-42.

Chen, J., Young, S. M., Allen, C., Seeber, A., Péli-Gulli, M. P., Panchaud, N., Waller, A., Ursu, O., Yao, T., Golden, J. E., Strouse, J. J., Carter, M. B., Kang, H., Bologa, C. G., Foutz, T. D., Edwards, B. S., Peterson, B. R., Aubé, J., WernerWashburne, M., Loewith, R. J., De Virgilio, C. ve Sklar, L. A. (2012). Identification Of A Small Molecule Yeast Torc1 İnhibitor With A Multiplex Screen Based On Flow Cytometry. ACS Chem Biol, 7(4):715-22.

Cüceloğlu, D. (2016). İnsan ve Davranışı. İstanbul: Remzi Kitabevi.

Çavuş, E. ve Özden, M. (2012). İlköğretim Öğrencilerinin Fen Ve Teknoloji Dersinde Fen Günlüğü Kullanımına İliskin Görüşleri. Adiyaman University Journal of Science, 2 (1), 34-48.

Celiker, H. D., Tokcan, A., ve Korkubilmez, S. (2015). Fen Öğrenmeye Yönelik Motivasyon Bilimsel Yaratıcılığı Etkiler Mi?. Mustafa Kemal Üniversitesi Sosyal Bilimler Enstitüsü Dergisi, 12(30), 167-192.

Çoban, G. ve Ergin, Ö. (2008). İlköğretim Öğrencilerinin Bilimsel Bilgiye Yönelik Görüşlerini Belirleme Ölçeği. İlköğretim Online, 7 (3), 706-716.

Dede, Y. ve Yaman, S. (2008). Fen Öğrenmeye Yönelik Motivasyon Ölçeği: Geçerlik ve güvenirlik çalışması. Necatibey Eğitim Fakültesi Elektronik Fen ve Matematik Eğitimi Dergisi, 2 (1), 19-37

Demir, R., Öztürk, N. ve Dökme, İ. (2012). İlköğretim 7. Sınıf Öğrencilerinin Fen Ve Teknoloji Dersine Yönelik Motivasyonlarının Bazı Değişkenler Açısından İncelenmesi.
Mehmet Akif Ersoy Üniversitesi Eğitim Fakültesi Dergisi, 12(23), 1-21

Durmaz, M. ve Akkuş, R. (2016). Mathematics Anxiety, Motivation And The Basic Psychological Needs From The Perspective Of Self-Determination Theory. Egitim ve Bilim, 41(183), 111-127.

Engin, D. C. (2009). Factors İnfluencing The Academic Achievement Of The Turkish Urban Poor. International Journal of Educational Development, 29, 17-29.

Eroğlu, S. ve Bektaş, O. (2016). STEM Eğitimi Almış Fen Bilimleri Öğretmenlerinin Stem Temelli Ders Etkinlikleri Hakkındaki Görüșleri. Eğitimde Nitel Araștırmalar Dergisi Journal of Qualitative Research in Education, 4(3), 43-67.

Erökten, S. (2010). Fen Bilgisi Öğrencilerinde Kimya Laboratuvar Uygulamalarının Öğrenci Endişeleri Üzerine Etkisinin Değerlendirilmesi. Hacettepe Üniversitesi Eğitim Fakültesi Dergisi, 38: 107-114

Glynn, S. M., Taasoobshirazi, G. ve Brickman, P. (2009). Science Motivation Questionnaire: Construct Validation With Nonscience Majors. Journal of Research in Science Teaching, 46(2), 127-146.

Gürbüz, R. ve Costu, B. (2004). Kitap İncelemesi "Aktif öğrenme, Prof. Dr. Kamile Ün Açıkgöz”. İlköğretim Online, $3(1), 23-24$.

İlhan, M. ve Öner, S. M. (2012). Matematik Kaygısı Ve Olumlu Olumsuz Mükemmeliyetçiliğin Matematik Başarısını Yordama Gücü, Mersin Üniversitesi Eğitim Fakültesi Dergisi, 8 (1), 178188.

Karakaya, F., Yılmaz, M. ve Avgin, S., S. (2018). Ortaokul öğrencilerinin Fen Öğrenmeye Yönelik Motivasyonlarının İncelenmesi. Kahramanmaraşs Sütçü İmam Üniversitesi Sosyal Bilimler Dergisi, 15(2), 359-374.

Karakaya, İ. (2009). Bilimsel Araştırma Yöntemleri. (Ed. A. Tanrı̈̈̆gen) Bilimsel Araştırma Yöntemleri. Ankara: Anı Yayıncilik.

Kuyper, H., Van der Werf, M. P. C. ve Lubbers, M. J. (2000). Motivation, Meta-Cognition And Self-Regulation As Predictors Of Long Term Educational Attainment. Educational Research and Evaluation, 6(3), 181-201.

Loveless, A. M. (2000). Creativity, Visual Literacy And İnformation And Communications Technology İn D. M. Watson and T. Downes (Editör) Communications and Networking in Education: Learning in a Networked Society. London: Kluwer Academic Publishers.

Mallow, J. V. ve Greenburg, S. L. (1982). Science Anxiety: Causes and Remedies. Journal of College Science Teaching, 11(6), 356-358.

MEB. (2017). İlköğretim Fen Bilimleri Dersi (3,4,5,6,7 ve 8 . Sınıflar) Öğretim Programı. Ankara: MEB Yayınevi.

Morgan, C., T. (2000). Psikolojiye Giriş. Hacettepe Üniversitesi Yayınları: Ankara.

Özkan, S. (2003). The Roles Of Motivational Beliefs And Learning Styles On Tenth Grade Students' Biology Achievement. Yayımlanmamıs Doktora Tezi, Ortadoğu Teknik Üniversitesi, Eğitim Bilimleri Enstitüsü, Ankara.

Scovel, T. (1978). The Effect Of Affect On Foreign Language Learning: A Review of the Anxiety Research Language Learning, 28(1), 129-142.

Sevinç, B., Özmen, H. ve Yiğit, N. (2011). Investigation Of Primary Students' Motivation Levels Towards Science Learning. Science Education International, 22(3), 218-232. 
Sönmez, V. ve Alacapınar, F. G. (2011). Örneklendirilmiş Bilimsel Araştırma Yöntemleri. Ankara: Anı Yayıncılık.

Uzun, N. ve Keleş, Ö. (2010). Fen Öğrenmeye Yönelik Motivasyonun Bazı Demografik Özelliklere Göre Değerlendirilmesi. Gazi Eğitim Fakültesi Dergisi, 30(2), 561584.

Watters, J. J. ve Ginns, I. S. (2000). Developing Motivation To Teach Elementary Science: Effect Of Collaborative And Authentic Learning Practices İn Preservice Education. Journal of Science Teacher Education, 11(4), 277-313.

Wolters, C. A. ve Rosenthal, H. (2000). The Relation Between Students' Motivational Beliefs And Their Use Of Motivational Regulation Strategies. International Journal of Educational Research, 33, 801-820.

Wynstra, S. ve Cummings, C. (1990). Science Anxiety: Relation with Gender, Year in Chemistry Class, Achievement and Test
Anxiety. 12th Midwetern Educational Research Association, Chicago.

Yenice, N., Saydam, G. ve Telli, S. (2012). İlköğretim Öğrencilerinin Fen Öğrenmeye Yönelik Motivasyonlarını Etkileyen Faktörlerin Belirlenmesi. Ahi Evran Üniversitesi, Kırşehir Eğitim Fakültesi Dergisi (KEFAD), 13 (2), 231-247.

Yıldırım, B. (2015). Fen Bilimleri Öğrenme Kaygı Ölçeği: Geçerlilik Ve Güvenirlik Çalışması. Anemon Muş Alparslan Üniversitesi Sosyal Bilimler Dergisi, 3(1), 33-43.

Yılmaz, H. ve Çavaş, P. (2007). Reliability and Validity Study of the Students' Motivation toward Science Learning (SMTSL). Questionnaire. Elementary Education Online, 6(3), 430-440.

Yolagiden, C. ve Bektaş, O. (2018). Sekizinci Sınıf Öğrencilerinin Fen Bilimleri Öğrenme Kaygıları İle Fen Bilimleri Öğrenme Yönelimleri Arasındaki İlişkinin İncelenmesi. Maarif Mektepleri Uluslararası Eğitim Bilimleri Dergisi, 2(2), 18-41. 